\title{
IN A LAND FAR, FAR AWAY: writing (in) French Polynesia
}

\author{
Lúcia Flórido \\ (The University of Tennessee Martin) \\ https://orcid.org/0000-0002-3088-9491
}

\section{ABSTRACT}

This article approaches, from a historical perspective, the contemporary literature of French Polynesia and the themes that are particular to it, a consequence of the complex relationship between the region and France. The first text about Tahiti dates back to the ${ }^{1} 8$ th century when the explorer Antoine de Bougainville disembarked on the island. The publication of his diary in 1771 marks the origin of a myth that promises, to this day, the possibility of an earthly paradise. Over the years, the Tahitian mirage was consolidated, eventually assimilating the 118 islands that make up French Polynesia and overcoming the singularities of each one of them. However, with the onset of 193 atomic detonations in the region (carried out by the French government between 1966 and 1996), the environment became conducive to the birth of the movement aimed at restoring ancestral languages and cultures. Instead of stories written by foreign authors about French Polynesia, native writers decided to take control of the narrative, which proposes to reflect the Mā'ohi identity as it exists within the context of living under the rule of France. Today, this literary body, more substantial and prominent as the cultural revolution grew in scope, is regarded by academics as the youngest in the world. If books in print still face intellectual prejudices and high costs, the internet has created copious opportunities for publishing online, allowing local authors to transcend the insularity that has limited them for centuries.

KEYWORDS: French Polynesian literature, Mā'ohi literature, colonial literature, Francophonie. 


\section{NUM PAíS MUITO DISTANTE: escrevendo (n)a Po- linésia Francesa}

\section{RESUMO}

Este artigo aborda, a partir de uma perspectiva histórica, a literatura contemporânea da Polinésia Francesa e os temas a ela particulares, consequência da relação complexa existente entre a região e a França. O primeiro texto sobre o Taiti data do século XVIII, quando o explorador Louis Antoine de Bougainville aí desembarcou. A publicação de seu diário em 1771 marca a origem de um mito que promete, até os dias de hoje, a possibilidade de um paraíso terrestre. Com o passar dos anos, a miragem do Taiti se consolidou, acabando por assimilar as 118 ilhas que compõem a Polinésia Francesa e por suplantar as singularidades de cada uma delas. No entanto, com o início das 193 detonações atômicas na região (efetuadas pelo governo francês entre 1966 e 1996), o ambiente se tornou propicio para a inauguração do movimento que visava restaurar as línguas e culturas ancestrais. Em vez de histórias escritas por autores estrangeiros sobre a Polinésia Francesa, escritores nativos decidiram assumir o controle da narrativa, que propõe refletir a identidade Mā'ohi tal qual ela existe no contexto do domínio francês. Este corpo literário, mais substancial e proeminente à medida que a revolução cultural cresceu em escopo, é atualmente considerado pelos acadêmicos como o mais jovem do mundo. Se livros impressos ainda enfrentam preconceitos e altos custos, a internet criou oportunidades copiosas para que se possa publicar online, permitindo que os autores locais transcendam a insularidade que por séculos os limitou.

PALAVRAS-CHAVE: Literatura da Polinésia Francesa, literatura Mā'ohi, literatura pós-colonial, francofonia. 


\section{French Polynesia: a brief introduction}

Since the 1970s, literary works originating in French Polynesia started to emerge in print and most recently online as well, reaching a more diverse reading public as access to the Internet became widespread. While native authors still struggle in order to be acknowledged outside their insular sphere, they have already carved a niche in the field of colonial and post-colonial studies. Novels, short-stories, poetry and essays examine the many issues stemming from the territory's particular political and geographical situation in regards to France. Politically, French Polynesia has two titles: overseas collectivity and overseas country with its own president. These confer to the region a substantial autonomy in relation to the continent, such as the right to administer local matters and to contest decisions voted by the French Parliament, which nonetheless still controls several sectors of the government such as defense, currency and, justice among others. Geographically, it remains one of the most isolated and distant domains of France: a flight from Paris to Tahiti takes about 20 hours. Extension-wise, the entirety of French Polynesia corresponds in size to the whole of the European Union, however most of its space is occupied by water: all the islands and atolls together make for a surface about 130 times smaller than France.

First of all, it is important to point out that what is called French Polynesia, a name that in itself suggests uniformity and conformity, is often mistaken or merged with Tahiti, the biggest, most populated island ( $68 \%$ of the population live there) and the seat of the capital Papeete. However, the country consists of five archipelagos (Society, Tuamotu, Gambier, Marquesas, and Austral), containing 118 islands and atolls, of which about half remain uninhabited. The archipelagos do share many common traits and their citizens speak Tahitian or Reo Mā'ohi (along with six local languages, French and, in special circumstances, English), but they likewise stand distinctive from each other due to geological, historical, and cultural particularities. Whereas the best part of works written before the twentieth century focused almost exclusively on the island of Tahiti and the majority of modern-day literature hails from there, unifying the five archipelagos under one name is reductive and onedimensional. It reproduces a pattern introduced by the first Europeans, who, in order to better comprehend the new lands they stumbled upon, concentrated their efforts on transforming complexity into simplicity: 
hence one people, one island, one culture, and one history. Pacific orientalism (referring to the term as introduced by Edward Said) was thus born when white men, who dreamed up the staple images that still thrive today, first set foot ashore and made contact with the islanders. The rapport between the two was established at unequal terms from the outset. These savages, branded as naive, docile and generous, existed in a state of nature already witnessed in the peoples of Asia, Africa and the Americas. Like the latter, through centuries of continuous assimilation, French Polynesians would eventually lose the power to define themselves with their own language. They would also lose their sovereignty as a nation, their sense of belonging to the greater Oceanic family and, finally, become whatever the enlightened visitors, later upgraded to the status of colonizers, deemed them to be.

\section{The myth of Tahiti through the ages: a historical perspective}

In 1521, Magellan, attempting to circumnavigate the globe, arrived in the Pacific. The questionable existence of an unknown continent in this immense newly found ocean, and the promise of incalculable riches, propelled the stream of expeditions that followed and became the ambition of every country with navigation capabilities: "Terra Australis Incognita [...] was the mirage that lured successive European ships into the Pacific." (SALMOND, 2009, p.462) With the finding of new lands, came the discovery of new peoples. While there are diaries in which encounters with natives have been cursorily mentioned, it took two hundred years until the first relevant text describing their history and social structures appeared in print. It will be the Age of Enlightenment, and one of its most renowned explorers, Louis Antoine de Bougainville, who will first seek to document the cultures of the South Pacific, reflecting the era's zest for investigating and cataloguing. He will also be the precursor of the myth of Tahiti, paradise found: "for the Age of Enlightenment, Tahiti was understood as another possibility of civilization or, more exactly, as an example of the beginning of everything."' (own translation, GRONDIN, 2008, p.51).

\footnotetext{
1 "Pour le siècle des lumières, Tahiti a été compris comme une autre possibilité de la civilisation ou, plus justement, comme un représentant de l'état initial des choses."
} 
Bougainville, the first Frenchman to circumnavigate the globe, arrived in Tahiti in 1768, where he spent nine days, and proceeded to write inexhaustibly about it in Voyages Autour du Monde. In his journal, he referred to the island as the New Cythera (mythological birthplace of Aphrodite), most likely inspired by Jean Antoine Watteau's rococo masterpiece The Embarkation for Cythera (1717). From Bougainville's text, in itself a mixture of science and fiction, the image of Tahiti as the island of love would soon materialize in literature. The explorer unquestionably gathered a considerable amount of data about the land and the people he encountered in Tahiti, especially taking into account his short stay. However, when recording what he believed an empirical chronicle of Tahitian life, his objectivity was compromised by a profound sense of awe about what he saw:

I have never met men so well built or so well proportioned: to paint Hercules and Mars we would not find more beautiful models. Nothing distinguishes their traits from European traits: and, if they were dressed, if they lived less in the open air and not under the hot sun, they would be as white as us. ${ }^{2}$ (own translation, BOUGAINVILLE, 1771, p.76)

In addition, the pattern of establishing comparisons between Paris and Tahiti, with the goal of facilitating the understanding of the latter by the first, easily led to outlandish assertions. For instance, he compared Tahitian villages to the Champs Elysées and Tahitian love of body painting to Parisian women's fascination with make-up. Manifestly, Bougainville tried to illustrate alterity by bringing it into a comfortable zone and bestowing upon this newfound Other the mask of sameness.

In 1770, one year before the publication of the first part of Bougainville's journal, Bricaire de la Dixmerie's Le Sauvage de Tahiti aux Français appears in print and becomes 'the first 'Tahitian' work in French literature."3 (own translation, GIRARD, 1997, p.31) In it, a native addresses a Frenchman in order to criticize the latter's country by contrasting their cultures, morals and politics. In the philosophical novel,

\footnotetext{
2 “Je n'ai jamais rencontré d'hommes mieux faits ni mieux proportionnés; pour peindre Hercule et Mars, on ne trouverait nulle part d'aussi beaux modèles. Rien ne distingue leurs traits de ceux des Européens; et, s'ils étaient vêtus, s'ils vivaient moins à l'air et au grand soleil, ils seraient aussi blancs que nous."

3 “le premier ouvrage 'tahitien' de la littérature française."
} 
Dixmerie emphatically describes Tahiti as a nation that devotes most of its time to love-making: "love is their most frequent need [...] nothing is an obstacle or a hindrance to its practice. One could say that this island is entirely devoted to its cult." (own translation, DIXMERIE, 1770, p.10) Following this statement, he declares that Europeans, favored by the natives for their more attractive appearance, were invited to partake in the practice of this so-called religion. For Dixmerie, being white and civilized automatically warranted special privileges. However, it is quite clear that his understanding of Tahitians as sensual and uninhibited had been tainted by information acquired directly from his friend Philibert Commerson, a doctor and naturalist who had circumnavigated the globe with Bougainville. Thus, the myth of an elusive 'Island of Love' such as devised by the explorer and related by Commerson became the source of inspiration to Dixmerie's narrative. Soon after, it would also serve as the point of departure to exotic literature about the South Seas, thus substantiating that: "literature preceded, in a way, the objective knowledge of Tahiti, renewed archetype of the paradisiac island." ${ }^{5}$ (own translation, DAUPHINÉ, 1985, p.198) If Dixmerie's Tahitian tale was the only one that preceded Bougainville's, a plethora of novels will follow the publication of Voyages Autour du Monde, contributing to the insidious and persistent obliteration of factual data on Tahiti.

A text different in intent (and yet similar in form and content) is Diderot's Supplément au Voyage de Bougainville, published in 1772. The philosophe also used the Tahitian model as basis for social-criticism and, to some extent, to advance his own political agenda: the need for an equalitarian society to exist as a prerogative for universal happiness and justice. He discusses, in a dialogue format, Tahitian government and several cultural aspects of the island, contrasting it with France's. For Diderot, who incidentally has never set foot anywhere in the South Pacific, Tahitian society (such as he had read about) exemplified the high standards of living against which every country should be contrasted and at which they all should aim. These hypothetical standards served as the jumping board for a philosophical principle that would not have been

4 "l'amour est leur besoin le plus fréquent [...] nulle entrave ne gêne à son effort. On dirait que cette île est entièrement consacrée à son culte."

5 "la littérature avait, en quelque sorte, précédée la connaissance objective de Tahiti, archétype régénéré de l'île paradisiaque.” 
possible without the prerogative of a paradise found. As he claims: "I have not travelled all corners of the universe, but I assure you that you will only find human condition to be happy in Tahiti." (own translation, DIDEROT, 1772, p.87) The yearning for finding a spot on Earth where liberty, equality and fraternity were actually possible appeared in a large segment of Enlightenment's intellectual discourse. Commenting on Diderot's take on Tahitian, Bernard Papin writes:

Tahitian utopia becomes thus the laboratory of ideas where Diderot's dream of a bourgeois society can be thought. The new American society promised by the Insurgents' revolution will soon manifest itself as the first historical incarnation of what he had ideally glimpsed in Tahiti. ${ }^{7}$ (own translation, PAPIN, 1988, p.105)

Several other late eighteenth-century authors such as Le Marquis de Sade, Madame de Monbart, and Restif de la Bretonne used Tahiti's natural setting as a hedonistic background and opted for a loose interpretation of Tahitian mores, which means that: "very few works [...] escape a series of clichés, lyrical and hyperbolical, tirelessly repeated, over which a great part of the vision that the Occidental has about the island half a world away." (GIRARD, 1977, p.26)

\section{Rewinding history: revitalizing ancestral cultures and finding one's voice}

To this day, the carefully crafted image of "paradise found" still promises to outsiders the utmost escapism, which must include what the holiday business names the 4 S's: sun, sea, sand and sex. Diane Commons, a renowned Polynesian photographer, started her own series of postcards as a reaction to the widespread romantic and over-sexualized depiction of the vahines, the scantily dressed, attractive, obliging young women

\footnotetext{
6 "je ne parcourrai point toutes les contrées de l'univers, mais je vous avertis seulement que vous ne trouverez la condition de l'homme heureuse que dans Tahiti." 7 “'L'utopie tahitienne n'est ainsi que le laboratoire d'idées où se pense la société bourgeoise dont rêve Diderot... La nouvelle société américaine que promet la révolution des Insurgents lui apparaîtra bientôt comme la première incarnation historique de ce qu'il avait idéalement entrevu à Tahiti.»

8 "bien peu d'ouvrages [...] échappent à une série de clichés, lyriques et hyperboliques, inlassablement répétés, sur lequel semble reposer pour une grande part la vision que l'Occidental possède de l'île du bout du monde."
} 
who came to embody Tahiti. She chose not to expose the female body as object and to concentrate on nature as subject. Commons explains that, while she would rather photograph the island as the complex space it actually is, postcards are meant to do exactly the opposite:

I try to create only beautiful images. That's the challenge [...]. What I saw through my lens was so majestic... and there I was, standing in the trash. Those two extremes really do exist in Tahiti. But I have to focus on only one. Tourists want to stay in the postcard." (KHAN, 2011, p.8)

Due to the strong influence of the tourism industry, the region's principal source of revenue, popular depictions of the South Pacific have remained, for centuries, deliberately dissociated from reality and indissociable from the name 'Tahiti' as imagined by Bougainville. The upshot of the image manipulation and exploitation has changed though:

the post-World War II era is characterized by the exportation of the myth and its images $[\ldots]$. Gradually, the myth acquired an economic value [...]. Tourism, thanks to its advertising techniques, has transformed the sociological, philosophical, and literary myth of the previous two centuries into a lucrative economic myth. (NICOLE, 2001, p.155-6)

But the authentic, factual Tahiti defies generalization and the island often disappoints as a vacation destination. Despite the vast amount of information currently available online about French Polynesia, visitors still arrive on Tahiti imagining it Bora Bora, Huahine or Moorea. As the center of government, home to the only university and birthplace of the cultural revolution: "Tahiti has its drawbacks - it is expensive, trafficchoked, noisy, corrupt, and Frenchfied." (THEROUX, 1992, p.361) Resorts strive to compensate for the tourists' disenchantment by recreating Bougainville's Tahiti with all the comforts of civilization.

Alongside the commercial exploitation of the myth of Tahiti, serious anthropological studies of Polynesian peoples, now also to be referred as Mā'ohi, have imparted vast amounts of unbiased information on all aspects of their history, cultural production, set of beliefs and way of life. Also unearthed by modern researchers is an extensive trove of stories and legends that date as far back as the time the archipelagoes were first settled by East-Asians. However, by reason of their oral nature, these narratives remained for the most part the subject-matter of anthropologists and historians. France declared Tahiti a protectorate in 1880, but it was only in the twentieth century that French became the official language. With 
the introduction of mandatory schooling in French, gate to most coveted jobs, Tahitian or Reo Mā'ohi and other autochthone languages, some of which are now considered endangered, gradually acquired a lower status. Children at school who lapsed into their mother tongue were punished by having to write over and over "I shall not speak Tahitian." Once formal education had been in place for several decades and had produced solidly literate natives, literature written in French started to appear. That is how Mā'ohi literature of French expression came to be considered by scholars as the youngest literature in the world.

If poetry dates from the 1970 s, when the movement towards recovering the lost and stolen identity started to take shape, it was only in 1991 that the first novel, Chantal Spitz's Île des Rêves Écrasés (Island of Shattered Dreams), was published. The point of departure of this literary awakening coincided with the beginning of the nuclear tests in the region. From 1966 to 1996, the French government tested over 180 nuclear weapons in the Mururoa and Fangataufa atolls. While violent protests were taking place on the streets, writing became the instrument of an intimate rebellion. Through it, the natives expressed their outrage towards the violation of their land, a primordial sacred space, and the status of existing (or subsisting) as an occupied territory. The wave of works (along with the revitalization of Reo Mā'ohi) that flourished during and in the aftermath of the atomic tests indicates how much French Polynesians expected to be recognized for their singularities and no longer to be seen as an appendix of somewhere, linked to them by force or need, dissimilar in everything else. Stereotypes, however, are insidious and powerful, entailing a concerted effort to painstakingly dismantle their many layers of established misunderstandings.

In order to deconstruct the myth of Tahiti, contemporary authors exploited this very myth, offering to the readers another take on paradise. The short-story L'Atoll du Renouveau (our translation, The Atoll of Revival), by Thibauld Marais, plays with the clichéd idea of escaping from a depressing Parisian existence in search of happiness in Tahiti. The main character, Georges, concentrates all his hopes of a more pleasurable life on the enticing prospects triggered by a postcard from a friend who had started anew in the South Pacific. Beset with restored enthusiasm, he quits his job, packs his suitcase, and boards a plane to Papeete. Upon his arrival, Georges finds himself enthralled by the mythical images of the popular imagination: blue ocean, lush vegetation, warm weather, and 
beautiful women. After a week, however, he goes from disillusion to disillusion. The tropical heat he so much craved ended up being too hot. The so-called vahines all looked alike in their costumes, being nothing but a mirage to please tourists. The city of Papeete was dirty and crowded, and the famous Tahitian hospitality was nowhere to be found. Not long after installing himself on the island, Georges met Pierre, who had also fled France with the same dreams and hopes, but:

established for several months in Polynesia, this proud man was appalled by all he saw. Everything irritated him, from the politics to the irregular bus schedules, including the tropical rain and the behavior of his native colleagues from work. ${ }^{9}$ (own translation, MARAIS, 2001, p.120)

Alex W. Du Prel, yet another author whose works paint a candid picture of French Polynesia, often contrasts the dreariness of subsistence in the islands against the postcard landscape inhabited by tourists. As he declared in an interview: "to sell a book, paradise must suffer, and in each of my books paradise suffers as it suffers practically in every book about Polynesia."10 (GAURIN, 2001) Not primarily a fictional writer but a journalist, he remains one of the most contentious voices against the French administration and the burdens it imposes on the lowincome natives with its staggering inefficiency. Du Prel contextualizes the political rebuke by placing it within the framework of reality, where ordinary people who live ordinary lives face extraordinary adversities, caused by an enormity of pointless regulations brought in from the continent. In Teiki, Tahitian Diver, the protagonist becomes victim of absurd red-tape. Officials discover that Teiki, the most skilled diver in the whole of French Polynesia, did not have the required paperwork that would allow for him to be a registered dive-master in charge of tourists. However, in order to acquire this certification, Teiki must go to France, a trip financially unviable for him. So, unemployment and reliance on

\footnotetext{
9 "établi depuis plusieurs mois en Polynésie, cet homme imbu de sa personne se disait outré par tout ce qu'il voyait. Tout l'irritait, de la politique au fonctionnement irrégulier des bus, en passant par les pluies tropicales et le comportement au bureau de ses collègues natifs de l'île."

10 "pour vendre un livre, il faut que le paradis souffre et, dans chacune de mes nouvelles, le paradis souffre comme il souffre dans pratiquement dans chaque livre écrit sur la Polynésie."
} 
government welfare comes as the only option to a man who until then proudly worked for a living. To summarize the scope of Teiki's problem, he concludes: "Past plagues and colonization have not succeeded in breaking the beautiful soul of the Polynesian people. But this thoughtless and heartless creeping bureaucracy may just succeed. A true cultural suicide." (DU PREL, 2011, p.17) Many of Du Prel's short stories reiterate the importance of preserving old Polynesian ways and valuing intrinsic characteristics of the Polynesian identity such as honesty, resilience, and strength. In Teiki's story, his identity - he had been a dependable, passionate dive-master, whose extensive knowledge of the ocean and its creatures resided at the heart of his fame within the diving community was revoked by law. His whole self was obliterated by the lack of a paper set to validate his existence and guarantee his means of subsistence. As a baffling consequence of excessive legislation, he became exactly what the administration derides: another idle native taking advantage of Mother France's generosity.

$\mathrm{Du}$ Prel also delves into the consequences of staying indifferent to growing ecological concerns, such as the dangers that global warming poses to the islands' complex ecosystem. A subject-matter that certainly does not belong within the confines of tourist resorts, it remains nonetheless of utmost importance to a region whose economy depends on the promise of unspoiled nature and paradise on earth. In Island Sorry, the inhabitants confront the inexplicable death of local lagoons, suddenly covered by algae that killed the reefs and the fish. In face of what is a disaster for a community that subsists from fishing, the hired specialist states: "as our little island is the most fragile environment, it is unavoidable for it to be the first affected by climate change. The proof is here. Your lagoon is dead." (DU PREL, 2011, p.5) In the same manner that global warming risks destroying a way of life, so does the introduction of foreign tenets and lifestyles as, for instance, the consumerist behavior unfamiliar to the natives until about 40 years ago. The whole relationship with the land and ocean, once viewed as sacred spaces, has been replaced by an overall attitude that, even when unintentional, desacralizes these spaces so that they can be exploited in the name of economic prosperity.

The need to recover and preserve Polynesian values in order to avoid obliteration became the central preoccupation of several authors at the forefront of the cultural revolution, such as the poet Henri Hiro, who declared in an interview: "the path we are on will only bring more 
and more loss [...] I think that Polynesians are looking at themselves and asking, What is happening to us? We are in the process of being completely annihilated!" (CHAZE, 2005, p.74) Once the sacred land of their forefathers loses its status as such, its inhabitants fail to locate the cultural compass, which, for centuries, had assisted in shaping who they were as a nation. The impression of existing in a vacuum, brought by physical, cultural and psychological isolation, appears as the main topic of Journal de Bord du Vide (our translation, Logbook of the Void), by Sybélia Guirao. In the short story, a narrator who dwells on her own feelings of emptiness compares it to a mindset that engulfs the whole of French Polynesia and its native populations alike. She writes: "Someone told me today: this feeling that you have in you, it's the Polynesian void." 11 (own translation, GUIRAO, 2001, p.75) Geographic isolation, the arrival and subsequent presence of the European and, most importantly, the merging of several different cultures left Tahitians without a solid ground upon which to build their identity. Commenting on the correlation between the sentiment of meaninglessness and an unremitting melancholy, Guirao states:

Polynesians are very suicidal... In other islands, the mixture of occidental and Polynesian cultures disturbs the reference points of the young Polynesian. Their parents speak a half-French or not at all... They have a hard time fitting in... they no longer know who they are, where they are or what they are good for. ${ }^{12}$ (GUIRAO, 2001, p.81)

In Lettre à ma Polynésie, Mickaelle-Hinanui Cauchois deals as well with the theme of individuality, national identity and self-awareness amidst a culture where "con-fusion" is the norm. She addresses her island in the hopes that it will assist her in finding an answer to what the real Tahiti is and, with this answer at hand, to finally discover her true self. Upon trying to define herself through her heritage, language and appearance, she concludes that: "For as long as the Earth turns, I'm not

\footnotetext{
11 'Quelqu'un m'a dit aujourd'hui: 'Ce sentiment que tu as en toi, c'est le vide de la Polynésie'."

12 "Les Polynésiens sont très suicidaires... Dans d'autres îles, le mélange des cultures occidentale et polynésienne trouble les points de repères du jeune polynésien. Ses parents parlent un demi-français ou ne parlent pas du tout...Il a du mal à s'insérer...Il ne sait plus qui il est, où il est ou à quoi il sert."
} 
sure I know how to recognize myself." ${ }^{\prime 3}$ (own translation, CAUCHOIS, 2001, p.113)

While the plea of authors from other Francophone regions of the world remains unified around a set of topics, some of which are similar to those studied above, many French Polynesian writers deem the whole idea of Francophonie as yet another way to mitigate their uniqueness. By making the five archipelagos and their many peculiarities fit within the concept of Francophonie, sameness prevails. Therefore, the urgent longing to erase the conventional postcard image, demystifying paradise and describing French Polynesia through a convincing, truthful standpoint, goes side by side with the desire to remain outside the protective circle provided by the cloak of Francophonie. Since the concept of Francophonie synchronizes under one language a group of nations geographically, culturally and socially diverse, Chantal Spitz rejects it altogether. She unifies Francophone countries by the emptiness left in place once French became their official language:

Francophonie does not concern me, I do not recognize myself or find myself in it. History produced me speaking-reading-writing French it did not shape me feeling-thinking French. I do not feel bound to French thinkers under the pretext of a common language. I feel deliberately bound to all the colonized thinkers to all the bruised beings because their history is mine their tear is mine. $\mathrm{O}$ the power of resemblance... ${ }^{14}$ (own translation, SPITZ, 2002)

The hostility against the colonizer, the dubious relationship with their language and the always-present influence of French cultural icons, which reshape, by superimposition, what was there long before, is another aspect of the struggle to release Polynesia from a forged set of pre-conceived notions. Writing about the nature of national heritage and the complications that arise from accepting as one's own what belongs to someone else, Spitz writes:

\footnotetext{
13 "En tant que la Terre tournera, je ne suis pas assurée de savoir me reconnaître." 14 “La Francophonie ne me concerne pas je ne m'y reconnais pas ni ne m'y retrouve. L'histoire m'a produite parlant-lisant-écrivant de langue française elle ne m'a pas façonée sentant-pensant français. Je ne me sens pas liée aux pensants français sous prétexte de langue commune. Je me sens délibérément liée à tous les pensants colonisées à tous les sentants meurtris parce que leur histoire est la mienne leur déchirure est la mienne. Ô la puissance de la semblance..."
} 
Paul Gauguin. A name that becomes one with the Marquesas ... as if a pleasure house [Maison du Jouir] and a tomb were enough to erase a people with thousand years of civilization. The tomb of Gauguin has thus become a mandatory stop in the same way as the Eiffel Tower ... if you have not seen Gauguin's tomb, you have not seen the Marquesas .$^{15}$ (own translation, SPITZ, 2003)

Guirao's idea of a "Polynesian void" acquires yet another meaning when imported symbols from the past and staple images still in circulation cease to occupy the center stage in literature. Once native writers encounter the possibility of a cultural reclamation, the next step consists in retrieving what was lost or hidden, putting it into words and, literally, rewriting their history.

\section{Writing and becoming: literature as a means of self-substantiation}

Ancient narratives from Polynesian peoples occupy a category of their own: they are oral in nature, even if they have been transcribed in the nineteenth century by English missionaries, the first also to put Reo-Ma'ohi into writing. For as long as Polynesian literature remained the subject matter of anthropologists, it was not judged by the same criteria applied to written literature. However, once stories transitioned from voice to paper, either in Reo-Mā'ohi or in French, many scholars in the continent criticized them as unauthentic. After all, Tahitian was not originally a written language, and French was not originally the language of Tahiti, which meant that Polynesian literature produced in French was not really literature.

A very interesting element in regards to indigenous francophone and colonial studies is the absence of scholarship on Mā'ohi writers; despite the fact that these indigenous writers actively contribute to the literary production of French Polynesia. The fact that France seems reluctant to acknowledge the validity of Mā>ohi literary production may indeed be indicative of the subtleties of racist colonial discourse. (MATEATA-ALLAIN, 2003)

15 "Paul Gauguin. Ce nom qui se confond avec les Marquises... comme si une maison du jouir et une tombe avaient suffi pour effacer un people aux mille années de civilisation. La tombe de Gauguin est ainsi devenue une halte marquisienne incontournable au même titre que la Tour Eiffel... si tu n'as pas vu la tombe de Gauguin tu n'as pas vu les Marquises" 
Since large French publishing houses view Mā'ohi literature as lacking in depth and sophistication, they have no vested interest in printing works that risk not selling because these do not appeal to the general French public. Therefore, French Polynesian authors see themselves forced to publish locally, making the process extremely expensive. The prohibitive cost of printing one single book results in a limited number of copies, which only circulate among a small circle of intellectuals and academics. So, despite the fact that a robust literary corpus exists, the titles remain virtually inaccessible to the majority of readers, especially to the Mā'ohi ones, who fall into the lowest income bracket and to whom books are luxuries they simply cannot afford. However, globalization has not bypassed French Polynesia, and the widespread access to the internet has opened the possibility of online publishing. Online journals, websites, blogs and the like remain the easiest way to access an untapped source of creative and critical material. In a way, the internet remains thus far the best means for native authors to share and publicize their work. French Polynesian authors were aware that, in order to erase the image of the bon sauvage perpetuated for centuries in foreign texts and dispersed all over the globe, it was capital that they took control of the discourse, the main tool to reclaim their identity. Once in print or online, it would be feasible to make their word travel from island to island, then from island to continent, finally reaching a substantial audience.

French, however, is not a very effective means to impart their intellectual production if they hope to cross cultural and linguistic borders and to reunite with other Mā'ohi writers. Whether it is French or Kaina, also known as Franitian (a Franco- Mā'ohi dialect that disrupts French phonetically, grammatically and lexically), language still presents itself as the most significant obstacle if they hope to reach all Polynesian readers. Most of the Pacific speaks primarily English and, secondarily, native Aboriginal or Polynesian languages. French, in this case, isolates more than unifies. This led scholars and translators to work towards making the texts also available in English. If Mā'ohi authors writing in French face linguistic isolation from their Oceanic family, they remain cut off from the French reading public as well, especially when taking into account that they feel detached from the whole of Francophone literature, as explained by Spitz. For a while now, the notion that French Polynesia should not align itself with Francophone countries, but, instead, should insert itself within the context of Oceania prevails. If, for the colonizer, 
French Polynesia is a conglomerate of islands and atolls separated by an almost infinite ocean, for Polynesians, the ocean is not a means of separation, but, on the contrary, the ocean is the catalyst that brings them together. Transoceanic crossers from the beginning of times, they braved immense distances with their outrigger canoes and populated the whole of the Pacific, from Australia to Easter Island. Borrowing the metaphor of the canoe to impart their intention, Polynesian writers of French expression strive to reconnect with their relatives dispersed all over the South Seas through their writing, a transoceanic conduit of transcendence, transgression and reunification. (STEWART e col., 2005)

Although France has been supportive of and welcoming to the natives' wishes to revitalize their ancestral culture, this same government, however, seems to mostly facilitate the renaissance of cultural aspects that directly enhance the tourist experience, which reiterate the clichéd assessment of Tahiti as "paradise found" and "Island of Love." As a result, dance, tattooing, music and the like gained momentum, to the detriment of literature, that would still be lagging behind with no hopes of catching up had they counted on support from the continent. As we have already seen, contemporary French Mā'ohi literature brings about issues that are most definitely not tourism material, such as poverty, struggles to be Mā'ohi in a French dominated society, subpar education, lack of jobs, pollution, bureaucracy, ecological concerns, etc. In addition, most Mā'ohi writers are women and, with their pen, they obliterate the image of the vahines, who still populate the fantasies of the middle-aged tourist. On the contrary, they talk about the women of every day Polynesia, who rarely have time to dance around chest-naked adorned with tiaras and leis.

Célestine Vaité, probably the best internationally known contemporary Tahitian Mā'ohi novelist, has succeeded in escaping the confines of her island. Since she writes in English, lives and publishes in Australia, she remains one of the best cultural ambassadors of her people. Having chosen English as her conduit, she reached a much larger audience, that was given access to a culture and a land which, while breathtaking in many aspects, is by no means paradise on earth. Women (all her protagonists are females) are far from being Gauguin's vahines: old, young, average looking, they struggle continuously with men whose arrested development is the source of the family's financial difficulties and heart-breaks. Men, in turn, are strangers to the tattooed hunks depicted in postcards, where they appear displaying their physicality or romancing 
their ladies. Vaite's men are irresponsible, lazy, often abusive, inadequate breadwinners, and perpetual drunks:

Expect to wait years for a typical Tahitian man to commit... A typical Tahitian man will have three nocturnal meetings a week, at least, with his mates... If you are depressed, lost, crying, your typical Tahitian man will pretend he can't see your suffering... [he] holds his baby as if it were a pack of taro... [he] believes it is beneath his dignity to show his woman affection. (VAITE, 2006, p. 91)

Therefore, Vaite's female protagonists live surrounded by other women and together they remain the stronghold of Tahitian society, where men play and women break their backs to pay the bills: "Oui, she's having a girl...It's more painful to push girls into the world because they don't want to be born. They resist. They know what they are in for in this world of misery." (VAITE, p. 46) Vaite's plea lies with the role of women within Tahitian culture and the importance of education as a means of independency from a substandard home-life. These women, a composite of herself and of female relatives, have strong character and fight continuously to remain afloat amidst a sea of uncertainty. Associated with the image of the breadfruit, the staple food of the Tahitian people and many times the only available source of nourishment for the narrator's family, they live in a matriarchal society in which men are unreliable both as providers and lovers.

We can thus conclude by saying that the future of literature written in French Polynesia and, with it, of Mā'ohi heritage lies, mostly, in the hands of those writers, female or otherwise, who understand that their text is a formidable catalyst of change. It allows them to reconquer their identity, retrieve aspects of their culture gradually lost since 1842, when France first took over, and preserve their intrinsic values to future generations. Moreover, by advocating for legitimacy and distancing themselves from a reductionist depiction of their homeland, they will reshape the outside world's perception of Tahiti, escapist destination par excellence, and reconnect with their oceanic family, which understands and shares the same struggles. There is no reason to purposefully disenfranchise some aspects of a culture to the benefit of others in order to promote tourism. In the vast space that comprises the whole of French Polynesia, there will always be room for tourists, whose travels will undoubtedly be much enhanced if they venture outside the resort and embrace Mā'ohi culture directly from the people, through their dances, but also through their 
books because the stories they tell are much richer than the ones told on their behalf.

\section{REFERÊNCIAS}

BOUGAinville, Louis Antoine de. Voyage Autour du Monde (1771). Disponível em: <http://lesamisdebougainville.wifeo.com/documents/Voyage_ autour_du_monde.pdf $>$. Acesso em: 20 nov. 2017.

CAUCHOIS, Mickaelle-Hinanui. Lettre à ma Polynésie. Nouvelle Vague. Tahiti: Au Vent des Iles, 2001, p.103-14.

CHAZE, Michou. The Source: an interview with Henri Hiro. Varua Tupu. Manoa: A Pacific Journal. Varua Tupu: New Writings from French Polynesia. University of Hawai'i Press. vol.17, n.2, p. 71-81, Winter, 2005.

DAUPHINÉ, James. Quelques aspects littéraires du mythe de Tahiti. L'Information Littéraire, vol.37, n.5, 1985, p.198-204.

DIDEROT, Denis. Supplément au Voyage de Bougainville. Disponível em: $<$ http://www.gutenberg.org/ebooks/6501>. Acesso em: 27 jan. 2018.

DIXMERIE, Bricaire de la. Le sauvage de Tahiti aux Français, Londres, 1770. Disponível em: <https://gallica.bnf.fr/ark:/12148/bpt6k844689>. Acesso em: 25 jan. 2018.

DU PREL, Alex W. Le bleu qui fait mal aux yeux et autres nouvelles inédites. Papeete: Éditions de Tahiti, 2011.

GIRARD, Yves. De l'exploration à l'utopie: notes sur la formation du mythe de Tahiti. French Studies: a Quarterly Review, vol.31, p.26-41, 1977.

GAURIN, Annick Teeeva. Alex W. du Prel, Portrait d'auteur et entretien. Île en Île, 2001. Disponível em: <http://ile-en-ile.org/alex-du-prel-portrait-dauteur/>. Acesso em: 10 abr. 2018.

GRONDIN, Aurélie. La dimension anthropologique de la vision du Pacifique à travers les récits de voyages français de 1766 à 1804. Mémoire de Master 2 «Sciences Humaines et Sociales. Université Pierre Mendès France. Grenoble, 2008. Disponível em: <https://dumas.ccsd.cnrs.fr/file/index/docid/292514/ filename/La_dimension_anthropologique_de_la_vision_du_Pacifique.pdf $>$. Acesso em: 3 fev. 2018.

GUIRAO, Sibélia. Journal de Bord du Vide. Nouvelle Vague. Tahiti: Au Vent des Iles, 2001, p.69-89.

KHAN, Miriam. Tahiti Beyond the Postcard: power, Place, and Everyday 
Life. University of Washington Press: Baltimore, 2011.

MARAIS, Thibauld. L'Atoll du Renouveau. Nouvelle Vague. Tahiti: Au Vent des Iles, 2001, p.117-130.

MATEATA-ALLAIN, Kareva. Ma'ohi women writers of colonial French Polynesia:passive resistance toward a post(-)colonial literature. Jouvert: a journal of postcolonial studies, vol.7, n.2, 2003. Disponível em: <https://legacy.chass. ncsu.edu/jouvert/v7i2/mateat.htm>. Acesso em: 12 set. 2017.

NICOLE, Robert. The Word, the Pen, and the Pistol: Literature and power in Tahiti. New York, SUNY Press, 2001.

PAPIN, Bernard. Sens et fonction de l'utopie Tahitienne dans l'œuvre de Diderot. Genève: Institut et musée Voltaire, 1988.

SAID, Edward W. Orientalism. New York, Vintage Books, 1979.

SALMOND, Anne. Aphodite's Island: the European Discovery of Tahiti. Berkeley: University of California Press, 2009.

SPITZ. Sur la Francophonie. Île en Île, 2002. Disponível em: <http://ile-en-ile. org/chantal-spitz-sur-la-francophonie/. Acesso em: 4 mar. 2018.

---. Héritage et Confrontation. Île en Île, 2003. Disponível em: http://ile-en-ile. org/chantal-spitz-heritage-confrontation/. Acesso em: 15 mar. 2017.

STEWART, F.; MATEATA-ALLAIN, K.; MAWYER, A. D., eds. Te Ao Mā'ohi: An overview. Manoa: A Pacific Journal. Varua Tupu: New Writings from French Polynesia. University of Hawai'i Press. vol.17, n.2, p.XI-XXI, Winter, 2005.

THEROUX, Paul. The Happy Isles of Oceania: paddling the Pacific. New York: G. P. Punan's Sons, 1992.

VAITE, Célestine. Frangipani. New York: Hachette, 2006.

Recebido em: 04/09/2018

Aceito em: 28/01/2019 